\title{
MEDIATION IN THE SYSTEM OF SOCIAL SERVICES PROVISION IN UKRAINE
}

\author{
Karpinska N. V., Sushyk N. S.
}

\section{INTRODUCTION}

Intensification of globalization and integration processes, reform of all public life spheres, implementation of European Union standards involves basic social principles revision, the main of which are the rule of law, democratic transformation, improving the quality of life and humanism. However, as the diversity of political and legal, social, psychological and pedagogical views, moral and ethical standards of each person, which is a structural element of society, it is in fact and practically impossible to avoid conflicts. Conflicts (disputes) are in fact one of the oldest phenomena of the individual and society. The history of human civilization is a reflection of various conflicts, ways of their solving and outcomes, consequences, as components of each epoch. The problem of conflict relations in society has always been relevant at different stages of social development ${ }^{1}$.

Modern legal systems are made to provide a wide range of dispute resolutions, so the parties can choose among them the most acceptable and effective resolving regime, taking into consideration the specifics, circumstances and desired outcomes. At the same time, the consequences of lockdown restrictions measures due to the coronavirus pandemic (COVID-19) that influenced and affected various spheres of public life did not escape the judicial system of the world and Ukraine, in particular. As a result, the national judicial system has become even more congested, trial length has increased and the efficiency of court proceedings has decreased ${ }^{2}$.

Mediation is one of the most common and popular alternative forms of conflict (dispute) resolution in modern democracies. Mediation has

${ }^{1}$ Олена Кірдан Поняття «медіація» та підходи до його трактування у сучасному науковому дискурсі. Педагогічний часопис Волині. №2 (13). 2019. С. 12-19. URL: https://evnuir.vnu.edu.ua/bitstream/123456789/16372/1/r_1-12-20.pdf.

${ }^{2}$ Юна Потьомкіна Сінгапурська Конвенція: 7 міцяців потому. Юридична газета. 14 травня 2020 p. URL: https://www.asterslaw.com/ua/press_center/publications/the_singapore_ convention_7_months_later/. 
been especially widespread and developed in Western Europe, the United States of America, Australia, and, more recently, in the countries of the former Soviet Union. Evidence of this is the legislative regulation of the mediation procedure in the Republic of Belarus, the Republics of Moldova and Kazakhstan, etc.

Mediation has existed in Ukraine for more than 20 years, but to date it has not become widespread and has not become a part to the dispute settlement culture. Over the past five years, the situation has significantly improved, as the state has recognized the need to develop this area in the context of implementing its commitments to ensure access to justice, increase investment attractiveness of Ukraine and facilitate the removal of social tensions in society.

The practical experience of applying the mediation procedure in our country confirms the high efficiency of this institution in the process of resolving conflicts (disputes). Thus, according to the Ministry of Justice of Ukraine, experiments have been actively conducted in courts since 2003 (in particular, in Kyiv, Kharkiv, Ivano-Frankivsk, etc.). There are a number of Regional Groups of Mediation on the territory of Ukraine united in the National Association of Mediators of Ukraine and the Ukrainian Center for Common Ground, which is actively involved in the implementation of reconciliation programs for victims and offenders and educational activities in this area. Also, there is a practice of applying restorative procedures. Practice is insignificant in scope, but shows that mediation in litigation has many advantages over the general judicial procedure for solving legal disputes. Regarding legal regulation, since 2010 more than ten draft laws on mediation had been registered in the Verkhovna Rada of Ukraine, but none of them was been adopted. At the same time, the last few years have seen a pattern - every time a bill on mediation is introduced in the Verkhovna Rada of Ukraine, such issues as mediation, pre-trial settlement of disputes gain wide resonance. But after the «failure» of the law once again, interest in mediation itself as well as in the need to legislate this process fades very quickly ${ }^{3}$.

The introduction of the institute of mediation as an alternative way of solving disputes is the subject of research by domestic and foreign experts - T. Bilyk, R. Gavrylyuk, I. Horodys'ky, N. Krestovs'ka,

3 Духневич А., Карпінська Н. Процедура медіації (примирення) у кримінальному провадженні щодо неповнолітнього: міжнародний аспект. Історико-правовий часопис. Луцьк: Східноєвроп. нац. ун-т ім. Лесі Українки, 2020. № 1 (15). С. 79-85 
N. Mazaraki, V. Motyl, N. Nestor, V. Rodchenko, L. Romanadze, D. Sibiliova, A. Sergeeva, S. Sergeeva, Bert Maan, Remko van Ri and others. At the same time, the questions of the legal regulation expediency of mediation in national legislation are in need to be answered and resolved. What are the existing draft laws, what are the prospects?

Also, taking into consideration the fact that on the one hand - the State Standard of Mediation as Social Service (mediation) ${ }^{4}$ regulates the provision of mediation as a social service, and on the other hand modern law enforcement practice indicates the need for significant refinement of this standard, the analysis of the legislative regulation of mediation as a social service is relevant, which, we assume, will identify existing gaps and single out ways to address them.

\section{Legal regulation of the institute of mediation in Ukraine}

The word «mediation» comes from the Latin «mediatio» intermediary, analogues are the words «mediation» (English), «médiation» (French), from the Greek «medos» - neutral, independent of the party ${ }^{5}$.

D. Sibiliov notes that «mediation is a process in which a neutral third party - a mediator - helps to resolve the conflict, contributing to a voluntary agreement between the conflicting parties. The mediator facilitates the process of communication between the parties, understanding the positions and interests, focuses the parties on their interests and seeks an effective solution to the problem, giving the parties the opportunity to reach a constructive agreement» ${ }^{6}$. The author determines the list of cases in which mediation is necessary, in particular, when it is necessary to make a decision as an outcome of negotiations and document it; when there are agreements between the parties that they cannot disclose to third parties (especially in court) and want to maintain confidentiality; in the case when irritation and emotions interfere with the effective communication of the parties; provided timeframe limitations and

\footnotetext{
4 Державний стандарт соціальної послуги посередництва (медіації): Наказ Міністерства соціальної політики України від 17.08.2016. URL: https://zakon.rada.gov.ua/laws/show/z1243-16\#Text.

5 Олена Кірдан Поняття «медіація» та підходи до його трактування у сучасному науковому дискурсі. Педагогічний часопис Волині. № 2 (13). 2019. C. 12-19. URL: https://evnuir.vnu.edu.ua/bitstream/123456789/16372/1/r_1-12-20.pdf.

${ }^{6}$ Сібільов Д. М. Медіація як система позасудових процедур. Проблеми цивільного права та процесу : Матер. наук.-практ. конф. (22 травн. 2010 р.). Х. : Нац. ун-т внутр. справ, 2010. С. 299-302.
} 
the need to save money; desire to remain in partnership or friendly relations in the future. Thus, mediation in the jurisdictional process is the last opportunity for the parties to return to constructive negotiations, to agree on contentious issues in order to ensure further cooperation in the future and to avoid undesirable consequences for both parties ${ }^{7}$.

In the draft law «On Mediation» № 3504, paragraph 4 of Art. 1 enshrines the definition of mediation as a «voluntary, extrajudicial, confidential, structured procedure, during which the parties with the help of a mediator (mediators) try to resolve the conflict (dispute) through negotiations» ${ }^{8}$.

A detailed definition of mediation is given in the Gap-analysis of the introduction of the institute of mediation in Ukraine conducted by experts in 2020: mediation is an active structured process in the form of dialogue, in which an independent third party (mediator) helps the parties to the dispute to solve the conflict using targeted and specialized communication and negotiation methods; the parties are invited to participate actively in a process that focuses on the needs, rights and interests of the parties ${ }^{9}$.

This document provides another, broader definition of mediation: mediation is a voluntary and confidential form of an alternative way of resolving disputes which is based on agreements between two or more parties aimed at solving disputes between two or more parties with concrete outcomes. A third party, an independent and impartial mediator assists the parties in negotiating as for solving the dispute. The role of the mediator is to help the parties find their own solution. By holding joint meetings and separate meetings (caucuses) with the parties, the mediator helps both parties to clearly identify issues for discussion, understand the position of each party and get closer to resolving the dispute $^{10}$.

Leading experts in the field of mediation (L. Romanadze, T. Bilyk, R. Gavrylyuk, I. Horodys'ky) highlight the main prerequisites for mediation: the desire of the parties for a peaceful settlement of the

\footnotetext{
${ }^{7}$ Там само.

8 Проєкт Закону Про медіацію № 3504 від 19.05.2020. URL: http://w1.c1.rada.gov.ua/pls/zweb2/webproc4_1?pf3511=68877.

9 Берт Маан Ремко ван Рі, Аліна Сергєєва, Світлана Сергєєва, Луїза Романадзе, Володимир Родченко. Gap-Аналіз впровадження інституту медіації в Україні. URL: https://www.pravojustice.eu/storage/app/uploads/public/5f5/f7d/2a9/5f5f7d2a9b5cb356474501. pdf.

${ }^{10}$ Там само.
} 
conflict (dispute) and the voluntary participation of them in the mediation procedure ${ }^{11}$.

Mediation differs from other alternative ways of solving conflicts by its characteristic features (specifics), the most important are: mediation is a special type of negotiation, a process that has a certain structure; the participation of a mediator is mandatory; the mediator cannot represent either party; the mediator should not investigate the evidence and establish the facts; the mediator cannot force or direct the parties to make a decision that he or she believes is correct or optimal; the mediator does not make a binding decision for the parties; a characteristic feature is the active role of the parties themselves in negotiations on the independent search for possible solutions. In the process of mediation, the realization that solutions cannot be imposed by a mediator significantly reduces the tension of all parties and reduces the probability that either party to the conflict will only defend its position ${ }^{12}$.

According to experts, the main advantages of mediation over the judicial method of disputes solutions are:

- time saving (mediation can last from several hours to several weeks (or in some complex cases, perhaps several months), while litigation can last from several years); cost savings (mediation costs are much lower than going to court, paying court fees, paying for lawyers). Mediation services are usually paid for by both parties to the conflict, while in litigation each party pays for the services of a lawyer separately, and court costs are shared between the parties in accordance with current Ukrainian legislation;

- informality. Mediation is a procedure that allows the parties to be more involved than in litigation, which contains a wide range of rules and procedures. The parties agree on the date and duration of each meeting (session), which gives them confidence in the further quality of this procedure. Topics discussed in mediation are also chosen by the parties to the conflict, not imposed by the court;

- flexibility and control. During mediation, the parties to the conflict, in contrast to the trial, control the entire course of negotiations. This means that they have more voting rights in the negotiations and stronger control over the outcomes. Flexibility in mediation also means that

${ }^{11}$ Медіація у професійній діяльності юриста : підручник / авт. кол.: Т. Білик, Р. Гаврилюк, І. Городиський [та ін.] ; за ред. Н. Крестовської, Л. Романадзе. Одеса : Екологія, 2019. С.101-103.

12 Там само. 
negotiations move as it will be convenient and comfortable for all parties;

- confidentiality. Mediation is a confidential procedure that guarantees non-disclosure and ensures the preservation of reputation. Confidentiality is one of the guiding principles of mediation. Unlike open litigation, mediation gives participants the opportunity not to disclose information outside of it;

- sustainability of the decision. Mediation allows you to find solutions that satisfy both parties to the conflict, which is almost impossible to obtain in court, guided by the rule of law. All agreements reached in mediation are realistic to implement, as both parties have mutually agreed and reached a joint decision to resolve the conflict.

The mediation procedure is based on a system of certain principles that take into consideration the experience of mediation in different countries, the mentality of the population and the legal traditions of a particular country. The principles of the mediation procedure were being crystallized in the process of practice, were being formulated in the documents of the mediation communities, and then enshrined in regulations ${ }^{13}$.

According to Art. 3 of the draft Law of Ukraine «On Mediation» № 3504 mediation is conducted by mutual consent of the parties to mediation, taking into account the principles of mediator's voluntariness, confidentiality, independence and neutrality, impartiality of the mediator, self-determination and equality of rights of mediation parties. This list of principles is not exhaustive ${ }^{14}$.

Analysis of the mediation community's scientific and practical achievements shows a conditional division according to the functional purpose of the mediation principles into organizational and procedural. Organizational principles characterize the features of mediation and the status of its participants. The procedural principles characterize the procedure for mediation ${ }^{15}$.

The principle of parties' to mediation self-determination and equality of their rights is enshrined in Art. 8 of the draft Law of Ukraine «On

${ }^{13}$ Мазаракі Н. А. Теоретико-правові засади запровадження медіації в Україні: дис. ... докт. юрид. наук: 12.00.01. Київ, 2019. С. 205.

14 Проєкт Закону Про медіацію № 3504 від 19.05.2020. URL: http://w1.c1.rada.gov.ua/pls/zweb2/webproc4_1?pf3511=68877.

15 Огренчук Г. О. Правове регулювання застосування медіації при вирішенні цивільно-правових спорів: дис. ... канд. юрид. наук: 12.00.03. Київ, 2016. С. 98. 
Mediation». The principle is - the parties to the mediation independently determine the range of issues under discussion, options for solving the conflict (dispute) between them, the content of the agreement based on the outcomes of mediation, terms and methods of its implementation, other issues of conflict (dispute) and mediation procedures taking into consideration the mediator's and other participants' in mediation recommendations. Final decisions are made exclusively by the parties to the mediation ${ }^{16}$.

The mediator acts as an intermediary, who organizes the mediation procedure, monitors the process itself, the parties' compliance with the rules and has the tools and relevant competencies, helps the parties to understand and realize each other's interests and needs. At the same time, the mediator does not make decisions for the parties, does not provide any advice to the parties on possible options for understanding and does not incline to make the optimal (in his opinion) decision. Thus, the options for solving the dispute, the parties generate themselves, and are responsible for their implementation ${ }^{17}$.

The principle of voluntariness is the parties have the right of personal expression of their will to conduct the mediation procedure and the freedom to terminate it at any stage of the mediation procedure. The essence of this principle also includes the power of the parties to make any decision to solve the conflict only by mutual consent ${ }^{18}$. The principle of voluntariness also applies to the mediator. Thus, if the mediator is aware of the impossibility of further constructive work in the mediation procedure, the lack of real desire of the parties to resolve the dispute, as well as for any other reasons that may interfere with mediation, he has the right to terminate negotiations and withdraw from them.

The principle of equality of rights of the parties to mediation is the existence of equal in content and scope of each party subjective rights. There may be no privileges or restrictions on the grounds of race, color, political, religious or other beliefs, sex, ethnic or social origin, property status, place of residence, language or other characteristics. The parties

16 Проєкт Закону Про медіацію № 3504 від 19.05.2020. URL: http://w1.c1.rada.gov.ua/pls/zweb2/webproc4_1?pf3511=68877

17 Можайкіна О. С. Поняття та зміст основних принципів медіації в цивільноправових відносинах. Актуальні проблеми вітчизняної юриспруденції. 2017. № 5. С.56

18 Йосипенко С. Т. Принципи медіації у приватно-правових відносинах. Науковий вісник Ужгородського національного університету. Серія «Право». 2015. № 35. С. 132. 
have the same rights to express their opinions, comments, set the agenda and assess the acceptability of proposals and terms of conciliation ${ }^{19}$.

The principle of confidentiality is that information on the preparation and conduct of mediation is confidential, unless the parties to the mediation agree otherwise. The mediator, the parties and other participants in the mediation have no right to disclose information about the mediation without the consent of the parties ${ }^{20}$. Confidentiality may relate to both the procedure itself and the content of what was said during the procedure by the parties and the mediator. The limits of confidentiality are pre-determined by all participants in mediation - the mediator together with the parties and other participants (experts, lawyers, representatives, assistants, relatives, etc.). The principle of confidentiality means that the participants in the process undertake not to use the information from the mediation process against each other and for other purposes.

Very often, during individual meetings with the parties separately (so-called caucuses) each party informs the mediator information that does not want to disclose to the other party. Given this, the mediator should also clarify the limits of such information confidentiality. It is worth noting the information obtained during individual meetings can directly affect the development of a mutually acceptable solution to the conflict.

The principle of neutrality and impartiality is the need for the mediator to adhere neutrality and impartiality in relation to the participants in the process, not to give preference to either party, to ensure balance. It is considered that the criterion of the mediator's neutrality is not only mediator's inner feelings, but the parties' to the conflict perception of his impartiality.

The principle of independence is separated from the principle of neutrality and means that mediator is independent of parties and other participants in the process. The principle of independence is independent not only from external but also internal factors that may affect the mediation procedure.

The principle of awareness. This principle is the parties should be informed of their legal and other positions that may significantly affect the future decision. Awareness is a certain guarantee that the mediation

\footnotetext{
${ }^{19}$ Там само.

${ }^{20}$ Там само.
} 
procedure will take place without hiding and omitting certain information and facts. This principle provides for the right of the parties to consult in advance with experts in various fields in order to obtain the necessary information that may be relevant to them.

The structure and flexibility principle in mediation. The structuring in the mediation procedure implies that the mediator must build negotiations in a clear sequence moving from one stage (phase, level) to another. Domestic and foreign practice shows that there are certain stages (phases, levels) of mediation. Mediator training involves the formation of procedural competence. Due to the structuring of mediation process it is possible to achieve the desired positive result in the settlement of the conflict. In contrast to the judicial process mediation involves an arbitrary and trusting nature of the process. Flexibility helps the parties to be ready for mutual listening and understanding as well as in accepting and understanding the interests and needs of the other party.

The principle of the result openness is that the parties make decisions that are real for both parties to the conflict in terms of time and space. The ways of resolving the conflict should be clear definable and acceptable to the parties to the dispute who can determine them independently. In addition the main task of mediation is to solve the conflict taking into account the interests and needs of all parties. Therefore it can be stated that the decision openness should also involve the fact that it takes into account those points that are important for the parties to the conflict ${ }^{21}$.

In the light of Ukraine-the EU Association Agreement it is important that the European Community recognizes the effectiveness of the mediation procedure and recommends its implementation as the main method of alternative dispute resolution at the pre-trial stage and during court proceedings reflected in Association Agreement between Ukraine, the European Union and the European Atomic Energy Community and their Member States ${ }^{22}$.

21 Медіація у професійній діяльності юриста : підручник / авт. кол. : Т. Білик, Р. Гаврилюк, І. Городиський [та ін.] ; за ред. Н. Крестовської, Л. Романадзе. Одеса : Екологія, 2019. С. 117.

22 Угода про Асоціацію України 3 Європейським Союзом та Європейським співтовариством 3 атомної енергії і їхніми державами-членами від 27.06.2014 ратифікована із заявою Законом № 1678-VII від 16.09.2014. URL: https://zakon.rada.gov.ua/laws/card/984_011. 
The Article 1 of the Agreement states that Ukraine and the EU should strengthen cooperation in the field of justice, freedom and security in order to ensure the rule of law and respect for human rights and fundamental freedoms. The countries of the European Union have agreed that ensuring the rule of law and better access to justice should include access to both judicial and extrajudicial methods of dispute resolution.

The European Council called on the Member States to introduce alternative out-of-court procedures including mediation as the main method of settling disputes at the Summit meeting in Tampere on 15 October $1999^{23}$.

In August 2019 Ukraine was among the 46 signatories of the United Nations Convention on Mediation in Singapore and that has become an important step towards the introduction of the mediation institution ${ }^{24}$. Nowadays the Convention has great potential to become one of the effective mechanisms for resolving disputes with rising arbitration costs and the global economic downturn due to the COVID-19 pandemic. According to the Singapore International Mediation Center (SIMC) the success rate of mediation is $70 \%$ worldwide and $85 \%$ in cases mediated by SIMC in 2017 indicating the high efficiency of mediation as an effective dispute resolution tool ${ }^{25}$.

Today Ukraine has already taken some steps towards ratification and implementation of the Singapore Convention on Mediation primarily it is the adoption of the above-mentioned the Draft Law «On Mediation» No. 3504 dated 19 May $2020^{26}$.

The purpose of the Draft Law «On Mediation» is to consolidate the possibility of conducting a mediation procedure at the legislative level which will consist in voluntary out-of-court settlement of a conflict (dispute) through negotiations between the parties with the help of a mediator.

The Draft Law determines legal fundamentals and procedure for conducting mediation in Ukraine. In particular it is assumed that:

${ }^{23}$ Владислав Ситюк Медіація та правові перспективи іiі розвитку в Україні. URL: https://radako.com.ua/news/mediaciya-ta-pravovi-perspektivi-yiyi-rozvitku-v-ukrayini.

24 Тетяна Сидоришина Медіація - нова фішка комунікації. Юридична газета online. №38-39 (692-693) від 17 вересня 2019 року. URL: https://yurgazeta.com/publications/practice/inshe/mediaciya--nova-fishka-komunikaciyi.html.

25 SIMC Clarifies Criteria for Serving on its Panel of Mediators. URL: http://simc.com.sg/blog/2018/06/11/simc-criteria-panel-mediators/.

26 Проєкт Закону Про медіацію № 3504 від 19.05.2020. URL: http://w1.c1.rada.gov.ua/pls/zweb2/webproc4_1?pf3511=68877. 
- the mediation procedure will be applied in any conflicts (disputes) arising from civil, family, labor, economic, administrative legal relations as well as in criminal proceedings while concluding reconciliation agreements between a victim and a suspect, defendant and in other spheres of public relations;

- individuals and legal entities will be able to apply to a mediator for mediation both before a court, arbitration court or international commercial arbitration during the preparatory hearings as well as during court or arbitration proceedings or while a court, arbitration court or international commercial arbitration decision execution;

- mediation will be conducted by mutual consent of the parties to the mediation in accordance with the principles of mediation;

- any individual with higher education and who has basic preparation program in the sphere of mediation in Ukraine or abroad will be able to acquire the status of a mediator;

- basic preparation program in the sphere of mediation shall consist of at least 90 hours of mediator training, including 45 hours of practical classes and will include theoretical knowledge and practical skills on the principles, procedure and methods of mediation, legal regulation of mediation, ethics of the mediator, negotiation and settlement of conflicts (disputes);

- preparation in the sphere of mediation will be provided by educational institutions as well as organizations ensuring conduct of mediation, associations of mediators, economic entities with any form of ownership and constitutional and legal form that have the right to provide services in the sphere of mediation or organize provision of such services;

- registers of mediators are maintained by associations of mediators, organizations that ensure conduct of mediation, as well as public authorities and local self-government bodies that engage mediators or use their services ${ }^{27}$.

An issue of whether or not a mediation procedure is mandatory or optional stays acute in the light of the discussion of the above-mentioned Draft Law «On Mediation». Appealing to international experience some experts are in favor of introducing the institution of mediation as a

27 Денис Малюська Схвалений Урядом законопроект про медіацію дозволить розвантажити судову систему. URL : https://www.kmu.gov.ua/news/denis-malyuskashvalenij-uryadom-zakonoproekt-pro-mediaciyu-dozvolit-rozvantazhiti-sudovu-sistemu. 
mandatory procedure. O. Tyutyun has a substantive view on the mediation and claims importance of the fact that not all disputes are subject to mediation, and given this fact alone mediation cannot be a mandatory pre-trial procedure in resolving disputes. At the same time $\mathrm{S}$. Stadnyk notes that in some countries, including the United States, there is a mandatory information session on the possibility of resolving the dispute through mediation but not mandatory mediation ${ }^{28}$.

Finally the confirmation that mediation is a visible, recognized and important topic at the state level is the promulgation of the Ordinace of the Cabinet of Ministers of Ukraine as of 24 March 2021 No. 276-r «On Approval of the Government Priority Action Plan to $2021 »^{29}$. Therefore, the priority areas for the Ministry of Justice of Ukraine Action Plan to 2021 are such as creation of a humanistic system of execution of criminal punishments and adoption of the relevant Law «On Child Friendly Justice» according to which the expected results should be effective prevention of minors recidivism and successful mediation with them; property rights protection, effective legal regulation within which the Ministry of Justice of Ukraine must ensure the possibility of using effective mechanism in Ukraine for the implementation of such agreements established by the UN Convention on International Settlement of Disputes ${ }^{30}$ by the end of 2021.

It should be noted that the action plan of the Ministry of Justice of Ukraine for 2021-2023 envisages increasing the role of alternative dispute resolution methods such as creation of effective both mediation and arbitration courts (arbitration) systems and educational measures to establish confidence of civil society institutions in out-of-court dispute resolution.

It is expected that the adoption of the Law of Ukraine «On Mediation» will confirm the European aspirations of Ukraine and will indicate the recognition of Directive 2008/52/EC of the European

\footnotetext{
${ }^{28}$ Дарина Сидоренко Новий законопроект про медіацію: за і проти Юридична газета online. 19 липня 2019 p. URL : https://yur-gazeta.com/golovna/noviy-zakonoproekt-promediaciyu-za-i-proti.html.

29 Про затвердження плану пріоритетних дій Уряду на 2021 рік : Розпорядження Кабінету Міністрів України від 24 березня 2021 року № 276-p. URL: https://zakon.rada.gov.ua/laws/show/276-2021-\%D1\%80\#Text.

${ }^{30}$ Конвенція ООН Про міжнародні угоди про врегулювання спорів за результатами медіації. URL: United Nations Convention on International Settlement Agreements Resulting from Mediationhttps://uncitral.un.org/sites/uncitral.un.org/files/singapore_convention_eng.pdf.
} 
Parliament of 21 May $2008^{31}$ which clearly defines the introduction of mediation in Ukraine among its further steps ${ }^{32}$.

\section{Mediation in the System of Social Services Providing}

It was clarified in the previous paragraph that at the present stage in Ukraine there is no legal regulation of the institution of mediation despite the experience of practical application of mediation, the functioning of the education and training system of mediators. The sphere of social services providing is an exception.

Provision of mediation as a social service is regulated by the State Standard of Social Mediation Service (hereinafter - the State Standard) approved by the Order of the Ministry of Social Policy of Ukraine of 17 August 201617 No. 892 (as amended from 7 August 2017) ${ }^{33}$ and Law of Ukraine «On Social Services» of 17 January $2019^{34}$.

Within the law the legislator provided for the need to promote reconciliation between the parties only in the context of divorce. The Article 111 of the Family Code of Ukraine ${ }^{35}$ provides for the court to take measures to reconcile the spouses if it does not contradict the moral principles of society. Also, Article 240 of the Civil Procedure Code of Ukraine $^{36}$, determines it possible to appoint a period of reconciliation for a spouse up to six months.

According to mentioned regulations intermediary (mediation) is a basic social service the provision of which to recipients of social services is provided by the authorities. On the one hand the State Standard is the only legal act governing the provision of mediation services, on the other hand, according to experts, it needs significant refinement since it is incorrect to use such terms as «mediation» and «intermediary» which are

31 Директива № 2008/52/ЄС Європейського парламенту і Ради «Про деякі аспекти посередництва (медіаціі) в цивільних та комерційних справах». URL: https://zakon.rada.gov.ua/laws/show/994_a95\#Text.

Офіційний сайт Національної асоціації медіаторів України. URL: http://namu.com.ua/ua/resources/news/pyeekashchkya-kha-ekaosg-v-toark-tuksuykhyekhryshekm-tsuyaets-ra-2021-u-n/.

33 Державний стандарт соціальної послуги посередництва (медіації): Наказ Міністерства соціальної політики України від 17.08.2016. URL: https://zakon.rada.gov.ua/laws/show/z1243-16\#Text.

34 Про соціальні послуги : Закон України від 17.01.2019 p. № 2671-VIII. URL: https://zakon.rada.gov.ua.

${ }_{35}^{35}$ Сімейний кодекс України. URL: https://zakon.rada.gov.ua/laws/show/2947-14\#Text.

36 Цивільний процесуальний кодекс України. URL: https://zakon.rada.gov.ua/laws/show/1618-15\#Text. 
close in meaning but denote two different stages of one service; the mediation service can be provided only in the second stage after the provision of the intermediary service, i.e. the person who is interested in receiving the mediation service does not have access to it until the first stage of the intermediary service is completed. Thus, there is terminological confusion associated with the names of contracts concluded during the provision of mediation services; the standard is quite complex in terms of document flow and almost impossible to meet in terms of requirements for the provision of service ${ }^{37}$.

If earlier the Law «On Social Services» ${ }^{38}$ : (with reference to which the State Standard on Mediation as Social Service was designed) defined social services as a set of measures to provide assistance to certain social groups who are in difficult life circumstances and cannot overcome them on their own then the new amended law provides for «... actions aimed at preventing difficult life circumstances, overcoming such circumstances or minimizing their negative consequences for persons / families who are in them (Article 1, Chapter1)». The preventive function mediation has become the good news in the new version of the document aimed to help prevent conflict and understand that conflict as not a negative phenomenon but a signal when some change is needed.

It is worth noting that today we have a situation when the law has already changed but the State Standard remains old one and needs to be updated and amended.

The analysis of the above normative documents gives us an understanding of the concept of social mediation service as a voluntary extrajudicial confidential structured procedure during which the parties, at least one of which belongs to vulnerable groups and / or are in difficult life circumstances to prevent or resolve the conflict carried out in accordance with the State Standard and consists of two stages such as preparatory activities and mediation negotiations. And here we see the features and nuances of social mediation services due to the stages of the process once mediators face.

What is the problem? It all starts with the first stage implying the stage of needs assessment carried out by social services. At this stage,

${ }^{37}$ Берт Маан, Ремко ван Рі, Аліна Сергєєва, Світлана Сергєєва, Луїза Романадзе, Володимир Родченко Gap-Аналіз впровадження інституту медіації в Україні. URL: https://www.pravojustice.eu/storage/app/uploads/public/5f5/f7d/2a9/5f5f7d2a9b5cb356474501.

38 Про соціальні послуги: Закон України від 17.01.2019 р. № 2671-VIII. URL: https://zakon.rada.gov.ua. 
the main difficulties are the loss of time, the need to fill out a large amount of documentation, the departure of the employee to the applicant who requested the service home, and ultimately a documentary evidence or non-confirmation of the conflict (which the party cannot resolve). Thus, a person's statement or voluntary declaration of will is sufficient to grant a social mediation service.

The next step is to address the issue of fee for social mediation service. As a result of the reform of the social system it has become possible to provide social services to different categories of people but it is not always absolutely free. On the one hand social service devaluation is the challenge of providing free social services because the person has not invested anything, so in view of this, he / she does not believe in the result and devalues the service itself. On the other hand, fee for social mediation service gives a responsibility and feeling of investment to those mediators' work providing such services. In order to determine the fee of the mediation service it is necessary to assess the property status, issue a separate document (certificate), and this is again a continuation of the procedure in time which makes it even longer and more complicated.

The third stage of the social mediation service is an intermediary stage which has become a cornerstone of discussions in the field of mediation. The analysis of the basic principles of mediation carried out in the first chapter shows that they (principles of mediation) are different from the rules of mediation. The mediator cannot advise, recommend, motivate, push to a certain decision the party to the process but the intermediary uses other tools differing to the mediator 's ones and has other opportunities. It is seen that a social worker can be an intermediary according to the State Standard.

Thus, intermediary is a mandatory stage. Being a very broad one this stage requires a documentary description, fulfillment of a lot of work, and in case of failure it ends with the need to move to the next stage, directly to mediation. The main challenge of the mentioned stage is the issue of its efficient implementation as well as the issue of evaluation and quality of performed work at this stage, and so on.

The next stage is an individual information and evaluation meetings with each participant to the conflict (dispute). At this stage, the media capacity of the conflict (dispute) is determined. Mediability is a set of factors that indicate the ability of the conflict (dispute) to be resolved through mediation, and the ability of the parties to participate in 
mediation, the admissibility, possibility and feasibility of using mediation to resolve a particular conflict between the parties at present.

The provision of social mediation services may take place in respect of conflicts in any sphere of public relations except those expressly prohibited such as conflict (dispute) between the victim and a person suspected of committing a crime or criminal offense; human trafficking; child abuse; domestic violence, if at least one party to the conflict is directed and / or undergoing a program for the abuser and the victim.

The next stage is mediation negotiations (joint or regular individual meetings), i.e. mediation itself, which is a structured process and involves appropriate stages: discovery, research of the parties' needs, search for a decision, decision making and formulation, inspection of its execution.

Ultimatally, the final stage provided by the State Standard on the provision of social mediation services is monitoring the implementation and clarification of agreements.

The grounds for refusal to provide a social mediation service are the following: the applicant does not belong to the category of persons for whom the social service is provided; no need for social services based on the results of assessing the needs of individuals / families that belong to the category provided by the State Standard; availability of information that the applicant or another party is a disabled person; the applicant does not belong to the category of persons receiving social services; detection of the fact of unreliability of the information submitted by the applicant, and documents that make it impossible to provide further social services.

Today the social mediation services providing in the family sphere and family conflicts (disputes) resolving are one of the most common and demanding types of conflicts emerging in Ukraine. The field of family relations is very diverse involving conflicts from marriage to adoption issues.

According to the Law of Ukraine «On Social Work with Families, Children and Youth» of 21 June $2001^{39}$ social work with families, children and youth is viewed as a professional activity aimed at preventing, minimizing the negative consequences and overcoming difficult life circumstances of families as well as children and youth by strengthening their ability to realize their own life potential. A special

\footnotetext{
${ }^{39}$ Про соціальну роботу з сім'ями, дітьми та молоддю : Закон України 21.06.2001 р. URL: https://zakon.rada.gov.ua/laws/show/2558-14\#Text.
} 
place among the authorized bodies that carry out such work is occupied by the centers of social services and their specialized institutions, as well as services for children. Centers for social services provide social services to various categories of the population, while the activities of children's services are aimed at ensuring the protection of the rights, freedoms and legitimate interests of children. There is room for mediation in activities of both mentioned social services subjects. The social services centers provide mediation and intermediarys services to persons / families in difficult life circumstances, while child services are involved in resolving disputes (between parents regarding place of residence of the child, the order of the child welfare and upbringing by those parents living separately, etc.). That is why most of the volunteer mediation projects implemented in Ukraine cooperate with the Centers for Social Services for Families, Children and Youth and the Services for Children. Experience of such projects shows that mediation helps to resolve a wide range of issues related to divorce, in particular, the rights and responsibilities of parents and children, adoption, guardianship and custody, conflicts with other relatives. Correct and clear understanding of the mediation essence by employees of the bodies as well as their activity itself has become crucial for the effective offer of mediation to the parties to the dispute. In this regard, volunteer projects usually begin with training and other information measures on mediation issues for employees of such bodies ${ }^{40}$.

Finally, it should be noted that only a limited number of employees of the social services system unfortunately have an idea of the mediation procedure despite the fact that the Law of Ukraine «On Social Services»" of 17 January 2019 refers to the intermediary (mediation) services. The number of employees of the social services system who have undergone basic training as a mediator is even smaller. In addition there is no clear mechanism for interaction between mentioned bodies and mediators.

We believe that employees of guardianship and wardship authorities as well as employees of the social services system (including centers of social services for families, children and youth) should be sufficiently qualified in mediation sphere to be able to inform about mediation services the parties to the conflict that can be implemented through the

40 Берт Маан, Ремко ван Рі, Аліна Сергєєва, Світлана Сергєєва, Луїза Романадзе, Володимир Родченко Gap-Аналіз впровадження інституту медіації в Україні. URL: https://www.pravojustice.eu/storage/app/uploads/public/5f5/f7d/2a9/5f5f7d2a9b5cb356474501. 
organization of both broad information about such a service and training in basic mediation skills of social workers. Mastering the competencies and tools of mediation by social workers will allow them to more effectively apply the acquired knowledge and skills in their professional activities and in offering social mediation services to the parties.

\section{CONCLUSIONS}

The institute of mediation in the Ukrainian legislation is new one and the legislation itself is in the process of formation nowadays. The issue of mediation legislative regulation will not lose its relevance for many years. The growing interest in mediation is evidenced by the increase in the number of mediators (intermediaries), the opening of mediation offices, the creation of public organizations-associations of mediators, providers of which are the NGO «National Association of Mediators of Ukraine» and the Ukrainian Mediation Center and in long run all agreements related to mediation. Realizing that the law is not necessary for the conducting of mediation, the adoption of a special law can be the necessary impetus for mediation promotion and mainstreaming. It is important that the adopted law is a framework one and does not lead to over-regulation of mediation.

The state standard is the only legal act that regulates the provision of mediation services and needs significant refinement since it is incorrect to use the terms «mediation» and «intermediary» which are close in meaning to denote two different stages of one service; the mediation service can be provided only as the second stage after the provision of the intermediary service, i.e. the person who is interested in receiving the mediation service does not have access to it until the first intermediary stage is completed; there is terminological confusion associated with the names of contracts concluded during the provision of mediation services; the standard is quite complex in terms of document flow and almost unfulfillable in terms of requirements for the service providing. Thus mediation service should become an independent basic social service.

The problem of lack of knowledge and information on the mediation procedure for guardianship and wardship authorities as well as employees of the social services system remains among the unresolved issues related to the provision of mediation as a social service in legal and practical terms which makes it impossible to inform the parties to the conflict about such a procedure. In its turn guardianship and wardship 
bodies do not have the authority to recommend the parties to the conflict to commence mediation and refer to mediation.

We see that first of all guardianship and wardship authorities should be empowered to promote the peaceful settlement of family conflicts and recommend mediation to persons who have applied to such bodies to protect their family rights and interests for which it is necessary to amend the Family Code of Ukraine.

Also, in order to achieve efficiency in the provision of mediation social services it is of first necessity to develop and implement a mandatory basic training course on mediation for employees of bodies engaged in social work with families, children and youth; to train employees of bodies engaged in social work with families, children and youth in order to train internal mediators in the system; to develop and implement a mechanism of interaction with mediators of bodies engaged in social work with families, children and youth.

\section{SUMMARY}

The article is devoted to the characteristics of the mediation institution in Ukraine and the peculiarities of mediation in the system of social services. The absence of mediation legislative regulation has been established and the need for the adoption of a framework law on mediation has been substantiated.

Based on the analysis of the Draft Law «On Mediation» as of 19.05.2020, the legal principles and procedures for conducting mediation in Ukraine and the basic principles of mediation are highlighted.

The legislative regulation of the social service of mediation has been studied. It is established that the State Standard is the only normative legal act that regulates the provision of social mediation services. The necessity of making changes to this normative-legal act is substantiated in view of incorrect use of the terms «mediation» and «intermediary», the presence of terminological confusion related to the names of agreements concluded during the provision of mediation services, etc.

Ways to solve the problem of lack of social workers awareness about mediation services and lack of established competencies for resolving conflicts (disputes) through mediation are proposed.

\section{REFERENCES}

1. Олена Кірдан Поняття «медіація» та підходи до його трактування у сучасному науковому дискурсі. Педагогічний 
часопис Волині. № 2 (13). 2019. С. 12-19. URL: https://evnuir.vnu.edu.ua/bitstream/123456789/16372/1/r_1-12-20.pdf.

2. Юна Потьомкіна Сінгапурська Конвенція: 7 міцяців потому. Юридична газета. 14 травня 2020 p. URL: https://www.asterslaw.com/ua/press_center/publications/the_singapore_c onvention_7_months_later/.

3. Духневич А., Карпінська Н. Процедура медіації (примирення) у кримінальному провадженні щодо неповнолітнього: міжнародний аспект . Історико-правовий часопис: науковий журнал. Луцьк: Східноєвроп. нац. ун-т ім. Лесі Українки, 2020. № 1 (15). С. 79-85.

4. Державний стандарт соціальної послуги посередництва (медіації): Наказ Міністерства соціальної політики України від 17.08.2016 URL: https://zakon.rada.gov.ua/laws/show/z1243-16\#Text.

5. Сібільов Д. М. Медіація як система позасудових процедур. Проблеми цивільного права та процесу : Матер. наук.-практ. конф. (22 травн. 2010 р.). Х. : Нац. ун-т внутр. справ, 2010. С. 299-302.

6. Проєкт Закону Про медіацію № 3504 від 19.05.2020. URL: http://w1.c1.rada.gov.ua/pls/zweb2/webproc4_1?pf3511=68877.

7. Берт Маан Ремко ван Рi, Аліна Сергєєва, Світлана Сергєєва, Луїза Романадзе, Володимир Родченко. Gap-Аналіз впровадження інституту медіації в Україні. URL: https://www.pravojustice.eu/ storage/app/uploads/public/5f5/f7d/2a9/5f5f7d2a9b5cb356474501.pdf.

8. Медіація у професійній діяльності юриста : підручник / авт. кол.: Т. Білик, Р. Гаврилюк, І. Городиський [та ін.]. Одеса : Екологія, 2019. 456 с.

9. Мазаракі Н. А. Теоретико-правові засади запровадження медіації в Україні: дис. ... докт.юрид. наук: 12.00.01. Київ, 2019. C. 205 .

10. Проєкт Закону України «Про медіацію» від 17.12.2015 р. № 3665 . URL: http://w1.c1.rada.gov.ua/pls/zweb2/ webproc4_1?pf3511=57463.

11. Огренчук Г. О. Правове регулювання застосування медіації при вирішенні цивільно-правових спорів: дис. ... канд. юрид. наук: 12.00.03. Київ, 2016. С. 98.

12. Можайкіна О. С. Поняття та зміст основних принципів медіації в цивільно-правових відносинах. Актуальні проблеми вітчизняної юриспрудениії. 2017. № 5. С. 56. 
13. Йосипенко С. Т. Принципи медіації у приватно-правових відносинах. Науковий вісник Ужгородського національного університету. Серія «Право». 2015. № 35. С. 132.

14. Угода про Асоціацію України з Європейським Союзом та Європейським співтовариством 3 атомної енергії i їхніми державами-членами від 27.06.2014 ратифікована із заявою Законом № 1678-VII від 16.09.2014. URL: https://zakon.rada.gov.ua/laws/ card/984_011.

15. Владислав Ситюк Медіація та правові перспективи іiі розвитку в Україні. URL: https://radako.com.ua/news/mediaciya-tapravovi-perspektivi-yiyi-rozvitku-v-ukrayini.

16. Тетяна Сидоришина Медіація - нова фішка комунікації. Юридична газета online. № 38-39 (692-693) від 17 вересня 2019 року. URL: https://yur-gazeta.com/publications/practice/inshe/ mediaciya--nova-fishka-komunikaciyi.html.

17. SIMC Clarifies Criteria for Serving on its Panel of Mediators. URL: http://simc.com.sg/blog/2018/06/11/simc-criteriapanel-mediators/.

18. Денис Малюська: Схвалений Урядом законопроект про медіацію дозволить розвантажити судову систему. URL : https://www.kmu.gov.ua/news/denis-malyuska-shvalenij-uryadomzakonoproekt-pro-mediaciyu-dozvolit-rozvantazhiti-sudovu-sistemu.

19. Дарина Сидоренко Новий законопроект про медіацію: за i проти Юридична газета online.19 липня 2019 року. URL: https://yurgazeta.com/golovna/noviy-zakonoproekt-pro-mediaciyu-za-i-proti.html

20. Про затвердження плану пріоритетних дій Уряду на 2021 рік : Розпорядження Кабінету Міністрів України від 24 березня 2021 року № 276-p. URL: https://zakon.rada.gov.ua/laws/show/ 276-2021-\%D1\%80\#Text.

21. Конвенція ООН Про міжнародні угоди про врегулювання спорів за результатами медіації. URL: United Nations Convention on International Settlement Agreements Resulting from Mediation https://uncitral.un.org/sites/uncitral.un.org/files/singapore_convention_ eng.pdf.

22. Директива № 2008/52/СС Свропейського парламенту і Ради «Про деякі аспекти посередництва (медіації) в цивільних та комерційних справах». URL: https://zakon.rada.gov.ua/laws/show/ 994_a95\#Text. 
23. Медіація та діалог - в плані пріоритетних дій уряду на 2021 рік. Офіційний сайт Національної асоціації медіаторів України. URL: $\quad$ http://namu.com.ua/ua/resources/news/pyeekashchkyakha-ekaosg-v-toark-tuksuykhyekhrysh-ekm-tsuyaets-ra-2021-u-n/.

24. Про соціальні послуги : Закон України від 17.01.2019 р. № 2671-VIII. URL: https://zakon.rada.gov.ua

25. Сімейний кодекс України. URL: https://zakon.rada.gov.ua/ laws/show/2947-14\#Text.

26. Цивільний процесуальний кодекс України. URL: https://zakon.rada.gov.ua/laws/show/1618-15\#Text.

27. Про соціальну роботу з сім'ями, дітьми та молоддю: Закон України 21.06.2001 p. URL : https://zakon.rada.gov.ua/ laws/show/2558-14\#Text.

\section{Information about the authors:} Karpinska N. V.

Candidate of Law Sciences,

Associate Professor at the Department of Criminal Law and Procedure, Associate Professor at the Department of Civil and Juridical Disciplines, Lesya Ukrainka Volyn National University 13 Voli ave., Lutsk, Volyn region, 43025, Ukraine

Sushyk N. S. Candidate of Pedagogical Sciences, Associate Professor, Associate Professor at the Department of Social Work and Pedagogy of the Higher School, Lesya Ukrainka Volyn National University 13 Voli ave., Lutsk, Volyn region, 43025, Ukraine 